\title{
Ларькина Н.И.
}

\section{Особенности методических приемов преодоления нескрещиваемости между видами рода nicotoana}

ФГБНУ «Всероссийский научно-исследовательский институт табака, махорки и табачных изделий» (Россия, Краснодар)

doi $10.18411 /$ scc-05-2018-14

idsp 000001:scc-05-2018-14

\section{Аннотация}

Межвидовая гибридизация занимает значительное место при создании принципиально нового селекционного материала, так как некоторые признаки диких видов рода Nicotiana можно применять для его качественного улучшения. Несмотря на широкое распространение метода при использовании выявляется ряд трудностей генного и фенотипического характера, не позволяющих привлекать многие дикие виды в гибридизации. Главное препятствие - нескрещиваемсть видов. Для ее преодоления использовался ряд методических приемов, позволяющих создать новый селекционный материал.

Ключевые слова: Межвидовая гибридизация, виды, род, методы культуры in vitro, компоненты раствора, питательная среда, каллус, органогенез, укоренение, гибридные семена, стерилизация, бокс.

Род Nicotiana характеризуется широким полиморфизмом, огромным коэффициентом размножения, самофертильностью, способностью к вегетативному размножению, устойчивостью к различным заболеваниям и другими возможностями. Представленные признаки, как отмечал М.Ф. Терновский $(1995,1958)$, способствовали развитию научно-исследовательских работ по межвидовой гибридизации в роде Nicotiana.

Целью исследований было создание нового исходного селекционного материала на основе межвидовой гибридизации при разработке и использовании комплекса методов и приемов, позволяющих преодолеть нескрещиваемость видов.

В исследованиях в качестве материнской формы использовали вид Nicotiana tabacum Lin. (сорта Иммунный 580 и Дюбек 44) (2n=48 хромосом), который относится к секции Geninae Goodspeed, сем. Пасленовых.

Опылителями служили дикие виды рода Nicotiana - Nicotiana debneyi Domin $(2 \mathrm{n}=48$ хромосом), Nicotiana rosulata Domin $(2 \mathrm{n}=40$ хромосом), Nicotiana amplexicaulis Burbidge $(2 \mathrm{n}=36$ хромосом).

При применении специализированных методик и приемов были получены стерильные межвидовые гибриды.

При создании гибридов использовали методы культуры in vitvo, применяя опыление in vitro, индуцирование каллуса из семян, листа и стебля, органогенеза и укоренения побегов.

Для межвидовой гибридизации применялся метод опыления in vitro, при этом заранее кастрировали бутоны цветков у растений материнских форм, изолировали от пыльников пестики за 2 дня до ожидаемого цветения, на пестики надевали специальные изоляторы, завязывая их тонкими нитками.

Также заранее собирали пыльники у бутонов цветков диких видов за 2 дня до полного их цветения, далее пыльники размещали в небольшие чашки Петри, где они созревали, образовывая пыльцу.

Для проведения опыления в условиях in vitro, стерилизовали специализированный бокс ультрафиолетовыми лучами ламп в течении 2-х часов. Далее, в специальных условиях бокса со всем необходимым материальным 
оснащением, стерилизованным в автоклаве, проводили скрещивание. Подготовленные бутоны, размещенные в небольшие матерчатые мешочки, стерилизовали в стакане с 12 $\%$ перекисью водорода в течение 7 минут и 2 раза по 5 минут промывали стерилизованной дистиллированной водой. Затем асептически вычленяли семяпочки вида N. tabacum с плацентой, помещали в большие чашки Петри, опыляя их пыльцой, предварительно стерилизованной в боксе 20 минут ультрафиолетовыми лучами. Опыленные плаценты с семяпочками переносили в пробирки на стерильные модифицированные питательные среды, включающие следующие компоненты в литре раствора:

— макросоли: Сa (NO3)2 - 500 мг; KNO3 - 125 мг; MgSO4 · 7Н2O - 125 мг; KHPO4 - 125 мг;

— микросоли: $\mathrm{MnSO} 4 \cdot 4 \mathrm{H} 2 \mathrm{O}$ - 3 мг; $\mathrm{ZnSO} 4 \cdot 7 \mathrm{H} 2 \mathrm{O}-0,5$ мг; $\mathrm{H} 3 \mathrm{BO} 3$ - 0,5 мг; $\mathrm{CnSO} 4 \cdot 5 \mathrm{H} 2 \mathrm{O}-0,025 \mathrm{мг}$;

- специализированные добавки: инозит - 100 мг; гидролизат казеина 500 мг; тиамин -1 мг; рибофлавин - 0,25 мг; никотин - 1мг; глицин - 0,5 мг; пиридоксин - 0,2 мг; пантетанат - Са - 7 мг; сахароза - 35 г; агар-агар -8 г.

На 8-е сутки после опыления смотрели в пробирках число завязавшихся семян, оплодотворенные семяпочки разрослись. Опылено было от 35 до 182 завязей.

На 8-е сутки число оплодотворенных разросшихся семяпочек было с диким видом N. rosulata - 520; с диким видом amplexicaulis - 174; с диким видом N. debneyi 54. Гибридных семян на плацентах N. tabacum было обнаружено на 30 сутки с диким видом N. rosulata - 141 шт., с amplexicaulis - 158 шт., с N. debneyi - 38 шт. Часть собранных гибридных семян, полученных с используемыми дикими видами опылителями, в условиях in vivo не прорастали. Оставшиеся гибридные семена проращивали в условиях in vitro, используя рекомендации Р.Г. Бутенко (1964, 1971). Получили слабые проростки на специализированных питательных средах. Их размножали в условиях in vitro. Каллусные ткани индуцировали из семян, листьев и стебля проростков на питательной среде Мурасиге и Скуга (Бутенко Р.Г., 1971).

Образовался каллус массой 100-150 мг через 20-30 суток, его пассировали в условиях стерилизованного бокса на 30-40 сутки на свежую питательную среду. После первого пассирования из каллуса индуцировали органогенез на среде Мурасиге Скуга, изменяя соотношения стимуляторов (Бутенко Р.Г., 1971). Первые проростки на питательной среде в пробирках появлялись на 10-15 сутки. На 30-40 сутки продросшие проростки в наибольшем количестве укореняли в пробирках на питательной среде Уайта (Бутенко Р.Г., 1971). Массовое корнеобразование отмечалось у растений в пробирках на 30-35 сутки после высадки. У некоторых растений корни были слабо развиты. Из 80 побегов гибридной комбинации с диким видом N. debneyi у 20 растений образовалась корневая система из 60 побегов с присутствием хромосомного состава дикого вида N. rosulata корневая система образовалась у 25 побегов, из 60 побегов с диким видом N. amplexicaulis корни появились у 20 растений.

Оборудование бокса, стерилизацию посуды, питательных сред, их приготовление осуществляли по методики Р.Г. Бутенко(1964), основательницы этого направления. Пробирки с культурой in vitro ставили в камеру искусственного климата, где поддерживали температуру $25^{\circ} \mathrm{C}$, влажность 70-75\%, освещение 5000 люксов.

Хорошо укоренившиеся растения в пробирках пересаживали в вазоны со стерильной смесью $1 / 3$ песка и 2/3 земли, покрывали химическими стаканами для поддержания постоянной влажности, выращивали в осеннее-зимнее время в теплице на искусственных подогреве и освещении. До цветения достигли 15 гибридных растений от опыления $\mathrm{N}$. amplexicaulis, 12 растений от опыления $\mathrm{N}$. debneyi и 11 растений от $\mathrm{N}$. rosulata. 
Выросшие гибридные растения были стерильны, цветки опадали, семена не завязывались. Подсчет числа хромосом в соматических клетках корешков показал, что в гибридных комбинациях: N.tabacum x N. amplexicaulis оно равно 42, т.e. гаплоидный набор хромосом N.tabacum - 24 и N. amplexicaulis - 18, в комбинации N.tabacum x N. debneyi - 48, т.е. гаплоидный набор хромосом N.tabacum - 24 и N. debneyi - 24, а у растений N.tabacum x N. rosulata - 44 хромосомы. Это гаплоидный набор N.tabacum 24 и N. rosulata -20.

Таким образом, при использовании метода культуры клеток тканей и органов в условиях in vitro были получены межвидовые гибриды, у которых материнской формой был N. tabacum, а опылителем дикий вид рода Nicotiana.

Эти гибриды послужили исходным материалом для изучения процессов микро-и макроспорогенеза, преодоления стерильности и получения форм «табачного типа», по фенотипу соответствующим культурному табаку (Ларькина Н.И., 2015, 2017).

$$
* * *
$$

1. Терновский М.Ф. Вопросы иммунитета у табака и махорки // Научно-технический бюллетень.Краснодар, 1935.- №8. - С. 2-4.

2. Терновский М.Ф. Результаты работ по межвидовой гибридизации в роде Nicotiana// Сборник науч.исслед. работ ВИТИМ.- Краснодар, 1958.- №150.-С.52-73.

3. Бутенко Р.Г. Культура изолированных тканей и физиология морфогенеза растений //М:Издат. Наука, 1964.-240 с.

4. Бутенко Р.Г. От свободноживущей клетки к растению// М.:Издат. Колос, 1971.-70 с.

5. Ларькина Н.И. Научные основы межвидовой гибридизации на плазме Nicotiana tabacum Lin. ㅇ// Монография ФГБНУ ВНИИТТИ - Краснодар: Изд. «Просвещение-Юг», 2015.-188 с.

6. Ларькина Н.И. Отдаленная гибридизация в биологии на примере рода Nicotiana// Книга ФГБНУ ВНИИТТИ.- Краснодар.- Изд. «Просвещение-Юг», 2017.- 96 с.

\section{Мадатова В.М., Бабаева Р.Ю., Заманова Ф.Д. Динамика изменения факторов гемокоагуляции у эпифизэктомированных животных на фоне облучения}

Бакинский Государственный Университет, Азербайджан (Россия, Баку)

doi $10.18411 /$ scc-05-2018-15

idsp 000001:scc-05-2018-15

\section{Abstract}

The influence of ionizing radiation on blood coagulation have epifizarnah animals revealed that animals epifizarnah time recalcification, thrombin time and the burden of free heparin dramatically shortened, tolerance of plasma to heparin is enhanced. When ionizing radiation epifizarnah animals observed prolongation of the time of recalcification, shortening of thrombin time and a sharp weakening of the tolerance of plasma to heparin, i.e., the pineal gland actively participates in the regulation of blood coagulation in normal and radiation pathology.

Keywords: epifiz, blood coagulation, recalcification, x-ray

Введение. После открытия ионизирующих излучений Рентгеном (1895) и Беккерелем (1896) были сделаны первые наблюдения их биологического действия. С этого времени целью радиобиологических исследований стало изучение процессов, происходящих при поглощении лучистой энергии, в итоге приводящих к радиационному эффекту, стимуляции физиологических функций, поражению или даже к гибели клеток, тканей и всего организма.

До середины XX столетия многочисленные исследования по проблеме радиационной биологии занимали многих ученых. Но эта наука как таковая стала 